\title{
Faktor-faktor yang Mempengaruhi Insentif Karyawan pada Apotek Kimia Farma Cabang Jambi
}

\author{
Reni Devita \\ Fakultas Ekonomi Universitas Batanghari Jambi, Indonesia
}

\begin{abstract}
Based on data obtained at Kimia Farma Pharmacy, it can be seen the number of employees, and incentives at Kimia Farma Pharmacy 2012 - 2017. Incentives are motivating employees to work with optimal abilities, namely as additional income outside the salary or wage that has been determined. Kimia Farma is the first pharmaceutical industry company in Indonesia, which was founded by the Indian government in 1817. Kimia Farma Pharmacy is located in Simpang Pulai Jambi. There are two factors that affect employee incentives, including 1) Material Factors with a value of 135.3 with very high criteria. 2) Non-factors with a value of 132.3 with high criteria. and gives to have an effect on positive to incentives of employees will increase by 1,047\%. Based on hypothesis that the incentives affects employees evidenced by $\mathrm{t}_{\text {count }} 5885>2,037$. This there significance between the effects incentives of employees in Kimia Farma Pharmacy. The conclusions drawn from incentives should be fostered and developed so that employees can work with more calm and comfortable, which in turn increases their. Kimia Farma Pharmacy gives incentive to employees who excel by showing a high initiative to resolve workplace issues. Thus employees will be motivated to developed ideas and initiatives that are useful in the workplace.
\end{abstract}

Keyword: incentives, employees, pharmacies

\section{PENDAHULUAN}

Manajemen sumber daya manusia diperlukan untuk meningkatkan kualitas sumber daya manusia. Sumber daya manusia sebagai aktor yang berperan aktif dalam menggerakkan perusahaan untuk mencapai tujuannya. Tercapainya tujuan perusahaan hanya dimungkinkan karena upaya karyawan untuk berkinerja dengan baik. Sumber daya manusia merupakan modal suatu organisasi baik organisasi pemerintahan maupun organisasi swasta untuk mencapai tujuan atau target yang ingin dicapai. Manusia merupakan unsur terpenting dalam setiap organisasi. Keberhasilan organisasi untuk mencapai tujuan dan sasarannya serta kemampuannya mengahdapi berbagai tantangan, baik yang bersifat internal maupun bersifat eksternal ditentukan oleh sumber daya manusia yang setepat-tepatnya.

Menurut Wilson (2012:4), salah satu sumber daya organisasi yang memiliki peran penting dalam mencapai tujuannya adalah sumber daya manusia. Oleh karena itu, pentingnya peran manusia dalam kompetisi baik jangka pendek maupun jangka panjang dalam agenda bisnis, suatu organisasi harus memiliki nilai lebih dibandingkan dengan organisasi lainnya. Organisasi yang berhasil dalam mempengaruhi pasar jika dapat menarik perhatian atau kelebihan yang dimiliki dalam berbagai hal dibandingkan dengan organisasi lain. Suatu cara yang berkaitan dengan sumber daya manusia agar dapat menjadi sumber keunggulan bersaing adalah melalui peningkatan modal manusia untuk dapat mengenal dan beradaptasi dengan lingkungan yang selalu berubah. Dewasa ini perubahan lingkungan bisnis yang sangat cepat menuntut peran sumber daya manusia dalam keunggulan bersaing. Hal ini juga berarti bahwa organisasi harus dapat meningkatkan hasil kerja yang diraih sekarang untuk dapat memperoleh hasil kerja yang lebih baik di masa depan. Di dalam organisasi adalah kompensasi yang memadai menurut Handoko (2011 : 121) kompensasi adalah segala sesuatu yang diterima para karyawan sebagai balas jasa untuk kerja mereka. Kompensasi juga merupakan penghargaan yang diberikan karyawan baik langsung maupun tidak langsung, finansial maupun non financial yang adil kepada karyawan atas kinerja mereka dalam mencapai tujuan organisasi, sehingga pemberian kompensasi sangat dibutuhkan oleh perusahaan manapun guna meningkatkan kinerja karyawannya. Adapun bentuk kompensasi finansial adalah gaji, tunjangan, bonus ( insentif ), dan komisi. Sedangkan untuk kompensasi non-finansial diantaranya pelatihan, wewenang dan tanggung jawab, penghargaan atas kinerja serta lingkungan kerja yang mendukung. Jadi untuk mendapatkan kompensasi yang sesuai dengan kinerja karyawan maka dibutuhkan pula karyawan-karyawan yang memiliki potensi yang baik guna tercapainya tujuan bersama. Oleh karena itu di dalam sebuah kompensasi terdapat beberapa kompensasi berupa kompensasi finansial yaitu insentif.

Menurut Dessler (2009:112) insentif adalah peningkatan gaji yang dihadiahkan kepada seorang karyawan pada satu waktu yang ditentukan dalam bentuk gaji pokok yang lebih tinggi, biasanya didasarkan 
secara eksklusif pada kinerja individual. Insentif umumnya dilakukan sebagai strategi untuk meningkatkan produktivitas dan efisiensi perusahaan dengan memanfaatkan perilaku pegawai yang mempunyai kecenderungan kemungkinan bekerja seadanya atau tidak optimal. Sehingga dengan adanya pemberian insentif yang diberikan kepada karyawan membuat kinerja yang dihasilkan pun sangat baik bagi perusahaan.

Pemberian insentif merupakan salah satu hal pokok yang harus diperhatikan oleh perusahaan. Semangat tidaknya karyawan bisa juga disebabkan oleh besar kecilnya insentif yang diterima. Apabila karyawan tidak mendapatkan insentif yang sesuai dengan besarnya pengorbanan dalam bekerja, maka karyawan tersebut cenderung malas bekerja dan tidak bersemangat yang ada akhirnya mereka bekerja semaunya tanpa ada insentif yang memadai, yaitu sebagaimana diharapkan oleh karyawan tersebut. Sedangkan menurut Rivai (2005:384) maupun Hariandja (2002:265) didalam buku Kadarisman mengemukakan bahwa insentif adalah bentuk pembayaran yang dikaitkan dengan kinerja, sebagai pembagian keuntungan bagi karyawan. Begitu juga menurut Mangkunegara (2002) mengemukakan bahwa insentif adalah suatu bentuk motivasi yang dinyatakan dalam bentuk uang atas dasar kinerja yang tinggi dan juga merupakan rasa pengakuan dari pihak organisasi terhadap kinerja karyawan dan kontribusi terhadap organisasi ( perusahaan ).

Para ahli di atas semakin menjelaskan bahwa insentif merupakan pemberian uang di luar gaji yang dilakukan oleh pemimpin organisasi sebagai pengakuan terhadap kinerja karyawan kepada perusahaan. Apabila insentif yang diberikan perusahaan sudah tepat, maka insentif yang diberikan akan meningkatkan kinerja karyawan dan insentif. Menurut Martoyo (2004:87) insentif dimaksudkan keadaan emosional karyawan di mana terjadi ataupun tidak terjadi titik temu antara nilai balas jasa karyawan dari perusahaan/ organisasi dengan tingkat nilai balas jasa yang memang diinginkan oleh karyawan yang bersangkutan. Dengan menyediakan layanan yang dimiliki seperti yang tersebut diatas, apotek kimia farma membuktikan bahwa layanan yang tersedia bukanlah hanya layanan farmasi (apotek) saja, tetapi apotek kimia farma juga menyediakan layanan klinik kesehatan, layanan laboratorium klinik dan optic

Untuk mengetahui perkembangan jumlah karyawan pada apotek kimia farma dalam lima tahun terakhir di lihat pada tabel dibawah ini :

Tabel 1

Daftar Jumlah Karyawan pada Apotek Kimia Farma Cabang Simpang Pulai Tahun 2013 - 2017

\begin{tabular}{crr}
\hline Tahun & Jumlah Karyawan ( Orang ) & Perkembangan ( \% ) \\
\hline 2013 & 18 & - \\
2014 & 22 & $(18,1 \%)$ \\
2015 & 18 & $38,8 \%$ \\
2016 & 25 & $28 \%$ \\
2017 & 32 & $28 \%$ \\
\hline
\end{tabular}

Sumber : Apotek Kimia Farma 2018

Tabel 1 diatas diketahui bahwa dalam lima tahun terakhir jumlah karyawan pada apotek kimia farma yaitu pada tahun 2013 sebanyak 18 orang karyawan, pada tahun 2014 sebanyak 22 orang karyawan atau mengalami peningkatan 22,2\% , pada tahun 2015 sebanyak 18 orang karyawan atau mengalami penurunan $(18,1 \%)$, pada tahun 2016 sebanyak 25 orang karyawan atau mengalami peningkatan 38,8\%, dan pada tahun 2017 sebanyak 32 orang karyawan atau mengalami penurunan 28\%. Faktor-faktor yang menyebabkan insentif antara lain adalah kemajuan, pengakuan, dan pekerjaan itu sendiri. Apabila faktor tersebut ditingkatkan akan membantu perbaikan prestasi, menurunkan perputaran dan absensi kerja serta menunjang sikap yang lebih baik terhadap manajemen. Dengan adanya insentif seorang karyawan akan merasa pekerjaannya telah dihargai sehingga membuatnya bekerja dengan sungguh-sungguh dan tentu saja akan memberikan keuntungan bagi organisasi. Syarat-syarat untuk mendapatkan insentif itu karyawan harus memenuhi absensi, karyawan bisa menyelesaikan pekerjaan sesuai dengan targetnya. Suatu organisasi yang mampu menciptakan kepuasan bagi karyawannya maka akan dapat meningkatkan disiplin kerja dan memperkecil rasa kejenuhan pegawai terhadap pekerjaan-pekerjaan yang bersifat monoton. Terlihat di tabel dibawah ini jumlah insentif yang diberikan oleh perusahaan dalam kurun waktu dari tahun 2013 - 2017. 
Tabel 2

Perkembangan Insentif Karyawan Apotek Kimia Farma Simpang Pulai Tahun 2013 - 2017

\begin{tabular}{cll}
\hline Tahun & Insentif/Org/Bulan ( Rp ) & Perkembangan ( \%) \\
\hline 2013 & 500.000 & - \\
2014 & 1.000 .000 & $100 \%$ \\
2015 & 1.200 .000 & $20 \%$ \\
2016 & 1.500 .000 & $25 \%$ \\
2017 & 1.000 .000 & $(33,3 \%)$ \\
\hline
\end{tabular}

Sumber : Apotek Kimia Farma, 2018

Tabel 2 diatas diketahui bahwa insentif pada Apotek Kimia Farma terus mengalami peningkatan selama tahun 2013 - 2016, yakni terlihat dari tahun 2014 - 2015 menurun sebesar 20\%. Demikian juga tahun 2015 - 2016 meningkat 25\%, serta dari tahun 2016 - 2017 perkembangan insentif pada Apotek Kimia Farma menurun sebesar 33,3\%. Tujuan dari penelitian ini adalah untuk mengetahui factor apakah yang mempengaruhi insentif karyawan pada apotek kimia farma simpang pulai Jambi.

\section{Metode}

Sumber data dalam penelitian ini adalah karyawan Apotek Kimia Farma yang diambil melalui wawancara dengan menyebarkan kuesioner. Data dan informasi yang diperoleh dianalisis secara deskriptif, untuk menganalisis respon karyawan mengenai insentif dan disiplin digunakan skala Likert, yang menggunakan 5 pilihan yaitu :

Tabel 3

Skala Likert

\begin{tabular}{llll}
\hline \multicolumn{1}{c}{ Sangat Tidak Setuju } & & STS & Bobot 1 \\
\hline Tidak Setuju & TS & & Bobot 2 \\
Cukup Setuju & CS & & Bobot 3 \\
Setuju & S & & Bobot 4 \\
Sangat Setuju & SS & Bobot 5 & \\
\hline
\end{tabular}

Sumber: Syekh, 2011

Populasi adalah sekumpulan individu dengan ciri-ciri sama ( satu spesies yang sama ) yang hidup dalam tempat dan waktu yang sama sedangkan dalam statistika populasi adalah sekumpulan data yang menjadi objek inferensi. (Syekh, 2011:13). Populasi yang langsung menjadi sampel dari penelitian ini adalah seluruh karyawan pada Apotek Kimia Farma tahun 2017 sebanyak 32.

\section{Analisis Deskriptif}

Dalam penelitian ini penulis akan menganalisis data yang diperoleh secara deskriptif kualitatif. Analisis dilakukan berdasarkan teori yang mempunyai kaitan erat dengan aspek yang diteliti. Menurut Umar (2013:23) analisis deskriptif kualitatif adalah menyesuaikan keadaan sebenarnya dan menggambarkan karakteristik peristiwa yang diamati serta menyimpulkan secara benar dan menyeluruh berdasarkan metode ilmiah dan menggunakan teori-teori yang dipelajari dan konsep yang relevan dalam permasalahan sebagai landasan berpijak dalam menganalisis. Untuk menganalisis permasalahan diatas digunakan skala penelitian dengan menghitung frekuensi skor setiap item pertanyaan. Seperti yang dikemukakan Umar (2013:225) bahwa perhitungan skor setiap komponen yang diteliti dengan mengalikan seluruh frekuensi data dengan nilai bobot. Rumus yang digunakan adalah :

Skor Terendah $=$ Bobot Terendah x Jumlah Sampel

Skor Tertinggi $=$ Bobot Tertinggi $\mathrm{x}$ Jumlah Sampel

Skor Terendah $=1 \times 32=32$

Skor Tertinggi $=5 \times 32=160$

Sedangkan untuk mencari rentang skala menurut Rangkuti (2001:58) digunakan rumus sebagai berikut:

Rentang Skala $=\frac{n(m-1)}{m}$

Dimana $: \mathrm{n}=$ Jumlah Sampel; $\mathrm{m}=$ Jumlah Alternatif Jawaban Item 
Rentang Skala $=\frac{32(5-1)}{5}$

$\mathrm{RS}=25,6$

Maka :

\begin{tabular}{|l|l|}
\hline $32-56,6$ & Sangat Rendah \\
\hline $57,6-82,2$ & Rendah \\
\hline $83,2-107,8$ & Sedang \\
\hline $108,8-133,4$ & Tinggi \\
\hline $134,4-160$ & Sangat Tinggi \\
\hline
\end{tabular}

\section{Hasil \\ Deskriptif Variabel Insentif \\ Insentif Material}

Tabel 4

Hasil Skor Responden Terhadap Indikator Insentif Material

\begin{tabular}{|c|c|c|c|c|c|c|c|c|}
\hline \multirow{3}{*}{ Item } & \multicolumn{8}{|c|}{ Frekuensi } \\
\hline & \multirow[t]{2}{*}{ Pernyataan } & SR & $\mathbf{R}$ & $\mathbf{C}$ & $\mathbf{T}$ & ST & Skor & Keterangan \\
\hline & & 1 & 2 & 3 & 4 & 5 & & \\
\hline 1. & $\begin{array}{l}\text { Besarnya pemberian bonus dari } \\
\text { perusahaan sesuai dengan hasil } \\
\text { kerja saya. }\end{array}$ & - & - & 3 & 14 & 15 & 140 & Sangat Tinggi \\
\hline 2. & $\begin{array}{l}\text { Perusahaan memberikan komisi } \\
\text { jika saya bekerja mencapai target. }\end{array}$ & - & - & 4 & 20 & 8 & 132 & Tinggi \\
\hline 3. & $\begin{array}{l}\text { Pemberian bonus dari perusahaan } \\
\text { sudah adil sesuai dengan hasil } \\
\text { kerja saya dan karyawan lain. }\end{array}$ & - & - & 3 & 17 & 12 & 137 & Sangat Tinggi \\
\hline 4. & $\begin{array}{l}\text { Perusahaan mendapatkan } \\
\text { tunjangan di masa tua. }\end{array}$ & - & - & 4 & 14 & 14 & 138 & Sangat Tinggi \\
\hline 5. & $\begin{array}{l}\text { Insentif yang saya terima dari } \\
\text { perusahaan memuaskan. }\end{array}$ & - & - & 4 & 20 & 8 & 132 & Tinggi \\
\hline 6. & $\begin{array}{l}\text { Insentif yang saya terima cukup } \\
\text { untuk memenuhi kebutuhan sehari- } \\
\text { hari. }\end{array}$ & - & - & 6 & 15 & 11 & 133 & Tinggi \\
\hline & Total & & & & & & 812 & \\
\hline & Rata-Rata & & & & & & 135,3 & Sangat Tinggi \\
\hline
\end{tabular}

Sumber : Data olahan

Berdasarkan Tabel 4 diatas diketahui skor jawaban sebesar 140 artinya besarnya pemberian bonus dari perusahaan sesuai dengan hasil kerja saya dinilai sangat tinggi oleh karyawan, 132 artinya perusahaan memberikan komisi jika saya bekerja mencapai target dinilai tinggi oleh karyawan,137 artinya pemberian bonus dari perusahaan sudah adil sesuai dengan hasil kerja saya dan karyawan yang lain dinilai sangat tinggi oleh karyawan, 138 artinya perusahaan mendapatkan tunjangan di masa tua dinilai sangat tinggi oleh karyawan, 132 artinya insentif yang saya terima dari perusahaan memuaskan dinilai tinggi oleh karyawan, 133 artinya insentif yang saya terima cukup untuk memenuhi kebutuhan sehari-hari, dan 135,3 artinya indikator insentif material dinilai sangat tinggi oleh karyawan pada Apotek Kimia Farma.

\section{Insentif Non Material}

Tabel 5

Hasil Responden Terhadap Indikator Insentif Non Material

\begin{tabular}{|c|c|c|c|c|c|c|c|c|}
\hline \multirow[b]{2}{*}{ Item } & \multicolumn{8}{|c|}{ Frekuensi } \\
\hline & Pernyataan & $\begin{array}{c}\text { SR } \\
1\end{array}$ & $\begin{array}{l}\mathbf{R} \\
\mathbf{2}\end{array}$ & $\begin{array}{l}\mathbf{C} \\
\mathbf{3}\end{array}$ & $\begin{array}{l}\mathbf{T} \\
4\end{array}$ & $\begin{array}{c}\text { ST } \\
5\end{array}$ & Skor & Keterangan \\
\hline 7. & $\begin{array}{l}\text { Perusahaan mendapat jaminan } \\
\text { sosial selama bekerja. }\end{array}$ & & 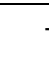 & 1 & 20 & 11 & 138 & angat Tinggi \\
\hline
\end{tabular}

sosial selama bekerja. 


\begin{tabular}{|c|c|c|c|c|c|c|c|c|}
\hline 8. & $\begin{array}{l}\text { Perusahaan memberikan insentif } \\
\text { lain selain bonus uang tunai seperti } \\
\text { penghargaan bagi karyawan yang } \\
\text { berprestasi. }\end{array}$ & - & - & - & 18 & 14 & 142 & Sangat Tinggi \\
\hline 9. & $\begin{array}{l}\text { Pemberian penghargaan dilakukan } \\
\text { secara obyektif sesuai penilaian } \\
\text { kinerja karyawan oleh manajer. }\end{array}$ & - & - & 8 & 19 & 5 & 125 & Tinggi \\
\hline 10. & $\begin{array}{l}\text { Perusahaan sering memberikan } \\
\text { penghargaan dan pujian pada } \\
\text { karyawan. }\end{array}$ & - & - & 1 & 21 & 10 & 137 & Sangat Tinggi \\
\hline 11. & $\begin{array}{l}\text { Perusahaan memberikan jaminan } \\
\text { sosial kepada karyawan. }\end{array}$ & - & - & 5 & 15 & 12 & 135 & Sangat Tinggi \\
\hline 12. & $\begin{array}{l}\text { Perusahaan telah memberikan } \\
\text { kesempatan promosi jabatan. }\end{array}$ & - & - & 13 & 17 & 2 & 117 & Tinggi \\
\hline & Total & & & & & & 794 & \\
\hline & Rata-Rata & & & & & & 132,3 & Tinggi \\
\hline
\end{tabular}

Sumber : Data olahan

Berdasarkan tabel 5 diatas diketahui skor jawaban sebesar 138 artinya perusahaan mendapat jaminan sosial selama bekerja dinilai sangat tinggi oleh karyawan, 142 artinya perusahaan memberikan insentif lain selain uang tunai seperti penghargaan bagi karyawan berprestasi dinilai sangat tinggi oleh karyawan, 125 artinya pemberian penghargaan dilakukan secara obyektif sesuai penilaian kinerja karyawan oleh manajer dinilai tinggi oleh karyawan, 137 artinya perusahaan sering memberikan pujian dan penghargaan pada karyawan dinilai sangat tinggi oleh karyawan, 135 artinya perusahaan memberikan jaminan sosial kepada karyawan dinilai sangat tinggi oleh karyawan, 117 artinya perusahaan telah memberikan kesempatan promosi jabatan dinilai tinggi oleh karyawan, 132,3 artinya indikator insentif non material dinilai tinggi oleh karyawan pada Apotek Kimia Farma.

Hasil rekap jawaban responden secara keseluruhan berdasarkan urutan prioritas penilaian terhadap insentif pada Apotek Kimia Farma tabel 6 berikut ini :

Tabel 6

Hasil Rekap Jawaban Responden Terhadap 12 Item Insentif

\begin{tabular}{|c|c|c|c|}
\hline No. & Indikator & Skor & Keterangan \\
\hline 1. & $\begin{array}{l}\text { Besarnya pemberian bonus dari perusahaan sesuai dengan hasil kerja } \\
\text { saya. }\end{array}$ & 140 & Sangat Tinggi \\
\hline 2. & Perusahaan memberikan komisi jika saya bekerja mencapai target. & 132 & Tinggi \\
\hline 3. & $\begin{array}{l}\text { Pemberian bonus dari perusahaan sudah adil sesuai dengan hasil } \\
\text { kerja saya dan karyawan yang lain. }\end{array}$ & 137 & Sangat Tinggi \\
\hline 4. & Perusahaan mendapatkan tunjangan di masa tua. & 138 & Sangat Tinggi \\
\hline 5. & Insentif yang saya terima dari perusahaan memuaskan. & 132 & Tinggi \\
\hline 6. & Insentif yang saya terima cukup memenuhi kebutuhan sehari-hari & 133 & Tinggi \\
\hline 7. & Perusahaan mendapat jaminan sosial selama bekerja. & 138 & Sangat Tinggi \\
\hline 8. & $\begin{array}{l}\text { Perusahaan memberikan insentif lain selain uang tunai seperti } \\
\text { penghargaan bagi karyawan berprestasi. }\end{array}$ & 142 & Sangat Tinggi \\
\hline 9. & $\begin{array}{l}\text { Pemberian penghargaan dilakukan secara obyektif penilaian kinerja } \\
\text { karyawan oleh manajer. }\end{array}$ & 125 & Tinggi \\
\hline 10. & $\begin{array}{l}\text { Perusahaan sering memberikan penghargaan dan pujian pada } \\
\text { karyawan. }\end{array}$ & 137 & Sangat Tinggi \\
\hline 11. & Perusahaan memberikan jaminan sosial kepada karyawan. & 135 & Sangat Tinggi \\
\hline 12. & $\begin{array}{l}\text { Perusahaan telah memberikan kesempatan promosi jabatan. } \\
\text { Total } \\
\text { Rata-Rata }\end{array}$ & $\begin{array}{r}117 \\
1606 \\
133,83\end{array}$ & $\begin{array}{l}\text { Tinggi } \\
\text { Sangat Tinggi }\end{array}$ \\
\hline
\end{tabular}

Sumber : Data olahan

Berdasarkan tabel diatas diketahui rata-rata skor jawaban sebesar 133,83 artinya insentif dinilai sangat tinggi oleh karyawan pada perusahaan telah memberikan kesempatan promosi jabatan. Jawaban karyawan tertinggi yaitu untuk indikator insentif non material dengan skor sebesar 142. Kenyataan ini menunjukkan bahwa bagi karyawan perusahaan memberikan insentif lain selain uang tunai seperti penghargaan bagi karyawan berprestasi dalam insentif agar karyawan lebih giat lagi dalam bekerja. 
Sedangkan jawaban terendah berkaitan dengan indikator insentif non material dengan skor 117. Kenyataan ini menunjukkan bahwa perusahaan telah memberikan kesempatan promosi jabatan kepada karyawan. Adapun rekap rata-rata skor untuk masing-masing indikator insentif pada Apotek Kimia Farma dapat dilihat pada tabel dibawah ini :

Tabel 7

Rekap Jawaban Indikator Insentif

\begin{tabular}{llll}
\hline No. & Indikator & Skor Rata-Rata & Keterangan \\
\hline 1. & Insentif Material & 135,3 & Sangat Tinggi \\
2. & Insentif Non Material & 132,3 & Tinggi \\
\hline
\end{tabular}

Sumber : Data olahan

Berdasarkan tabel diatas diketahui bahwa karyawan menempatkan indikator insentif material sebagai yang tertinggi dengan rata-rata skornya 135,3. Kenyataan ini menunjukkan bahwa karyawan untuk giat melaksanakan pekerjaannya. Dengan kata lain karyawan berusaha fokus untuk menyelesaikan pekerjaannya. Sedangkan indikator insentif non material dinilai terendah oleh karyawan dengan rata-rata skornya 132,3. Kenyataan ini menunjukkan bahwa karyawan harus lebih giat dan fokus dalam bekerja sehingga semua pekerjaan dapat diselesaikan dengan baik. Berdasarkan hasil perhitungan diperoleh angka $t_{\text {hitumg }}$ 5,885. Sedangkan $t_{\text {tabel }}$ sebesar 2,037. Dengan demikian ada pengaruh signifikan antara insentif terhadap karyawan pada Apotek Kimia Farma. Insentif karyawan merupakan variabel yang secara teoritis dan terbukti memiliki hubungan yang positif, yang pada akhirnya insentif akan mempengaruhi karyawan. Dengan demikian insentif akan berdampak searah pada karyawan. Dengan pemberian insentif yang semakin tinggi maka karyawan mempunyai semangat kerja yang diperoleh akan semakin baik. Sebaliknya insentif karyawan tidak baik apabila pemberian insentif semakin rendah. Insentif karyawan yang tinggi pada Apotek Kimia Farma ini sangat diharapkan oleh perusahaan untuk mencapai tingkat kerja yang telah direncanakan dan ditetapkan sehingga apa yang menjadi tujuan perusahaan dapat tercapai.

\section{SIMPULAN}

Berdasarkan hasil penelitian maka kesimpulan dalam penelitian ini adalah insentif pada Apotek Kimia Farma tinggi dengan skor rata-rata 133,83,dengan demikian insentif berpengaruh pada karyawan kimia farma.

\section{DAFTAR PUSTAKA}

Akhmad dan Jauhar Muhammad, Subekhi. 2012, Pengantar Manajemen Sumber Daya Manusia (MSDM), Jakarta : PrestasiPustaka

Dessler, Gary. 2009. Manajemen SDM. Buku 1. Jakarta :Indeks

Fahrul, 2016, Pengaruh Pemberian Insentif dan Kompetensi Karyawan terhadap Kinerja Karyawan PG Madukismo Yogyakarta, Skripsi, UNY, Yogyakarta.

Hasibuan, Malayu S. P. 2002. Manajemen Sumber Daya Manusia. Bumi Aksara. Jakarta.

Handoko, T. Hani. 2005. Manajemen Personalia dan Sumber Daya Manusia. BPFE UGM, Yogyakarta. James A. F, Stoner. Manajemen. Jakarta: Erlangga 